\title{
Proses Pemberdayaan Perempuan pada Program Sekolah Perempuan Capai Impian dan Cita-cita (Sekoper Cinta)
}

\author{
Dini Anjani Nurlatifah ${ }^{*}$, Deden Sumpena² and Fathin Anjani Hilman ${ }^{3}$ \\ 1*,2, 3 UIN Sunan Gunung Djati Bandung; 1*andininurlatifah35@gmail.com, 2dedensumpena67@gmail.com, \\ 3fanjanih@uinsgd.ac.id \\ *Penulis Korespondensi
}

Artikel Dikirim: 4 September 2020;

Artikel Diterima: 25 Oktober 2020;

Artikel Dipubikasikan: 16 Desember 2020

\begin{abstract}
Abstrak: Perempuan merupakan salah satu elemen masyarakat yang memiliki peran dan fungsinya. Perempuan sebagai mitra sejajar laki-laki harus bisa mengoptimalkan peran strategisnya dalam sebuah pembangunan. Namun untuk mencapai itu, perempuan masih dihadapkan dengan berbagai permasalahan yang beragam terlebih dalam lingkup gender. Oleh sebab itu untuk mengaktifkan dan mengoptimalkan peran perempuan, perlu didukung dan diberdayakan dengan memberikan mereka kesempatan dan peluang yang sama dengan laki-laki. Islam memandang laki-laki dan perempuan memiliki derajat sama yang membedakan hanyalah tingkat ketaqwaannya saja. Program Sekoper Cinta merupakan salah satu program pemberdayaan perempuan yang bertujuan untuk menyetarakan akses dan peran perempuan, dengan memberikan pengajaran dan berbagai pelatihan untuk memberikan kemampuan dan kekuatan untuk menjadi perempuan hebat yang mandiri. Tujuan dari penelitian ini adalah untuk mengetahui bagaimana proses pemberdayaan yang dilakukan oleh program Sekoper Cinta dan hasil yang dirasakan oleh perempuan dan lingkungan Kampung Munjul Kelurahan Karikil. Penelitian ini menggunakan metode penelitian deskriptis-analitis yang menggambarkan beberapa penemuan dengan menarasikannya dalam bentuk uraian. Dalam pengumpulan data penyusunan menggunakan metode observasi pastisifatif sebagai metode utama, sedangkan metode wawancara dan dokumentasi sebagai metode pelengkap. Hasil penelitian menunjukkan bahwa pemberdayaan yang dilakukan oleh program Sekoper Cinta ini cukup efektif, terlihat dari prosesnya yang tersusun secara sistematis dan memberikan dampak yang aplikatif di kalangan masyarakat yang dibuktikan dengan terjaganya hubungannya baik dalam keluarga serta munculnya rasa percaya diri pada masing-masing peserta Sekoper Cinta untuk mengekspresikan diri seperti ada yang mulai berdagang, membuka usaha tata rias pengantin, dan mampu terlibat dalam ruang-ruang publik seperti keterlibatan menjadi ketua RT dan aktif dalam organisasi masyarakat lainnya.
\end{abstract}

Kata Kunci: Kampung Munjul, Pemberdayaan Perempuan, Sekoper Cinta.

Abstract: Women are one of the elements of society who have their roles and functions. Women as equal partners of men must be able to optimize their strategic role in development. However, to achieve that, women are still faced with a variety of problems, especially in terms of gender. Therefore, to activate and optimize the role of women, it is necessary to be supported and empowered by giving them the same opportunities and opportunities as men. Islam views men and women as having the same degree. The only difference is the level of devotion. The Sekoper Cinta program is one of the women's empowerment programs that aims to equalize women's access and roles, by providing teaching and various trainings to provide the ability and strength to become independent great women. The purpose of this study was to determine how the empowerment process carried out by the Sekoper Cinta program and the results felt by women and the environment in Kampung Munjul, Karikil Village. This study uses a descriptive-analytical research method that describes several findings by narrating them in the form of descriptions. In collecting data the compilation used the method of pastisifative observation as the main method, while the interview and documentation methods were the complementary methods. The results showed that the empowerment carried out by the Sekoper Cinta program was quite effective, as seen from the systematically structured process and had an applicative impact in the community as evidenced by the maintenance of good relationships within the family and the emergence of selfconfidence in each of the Sekoper Cinta participants. to express themselves as if someone had started trading, opened a bridal make-up business, and was able to be involved in public spaces such as being the head of the RT and being active in other community organizations.

Keywords: Munjul Village, Sekoper Cinta, Woman Empowerment. 


\section{Pendahuluan}

Perempuan merupakan elemen masyarakat yang dinantikan kontribusinya dalam aspek pembangunan. Perempuan memiliki peran strategis yang perlu diaktifkan dan dioptimalkan agar bisa terintegrasi dalam suatu pembangunan. Namun untuk mencapai itu, perempuan masih dihadapkan dengan berbagai permasalahan yang beragam terkhusus dalam lingkup gender. Budaya patriarki yang merupakan warisan kehidupan jaman dulu masih banyak dirasakan oleh kaum perempuan di beberapa daerah yang membatasi arah gerak perempuan untuk berkontribusi di ranah publik. Dengan asumsi ini membuat perempuan yang telah menikah menggantungkan hidup sepenuhnya kepada suami, terlebih dalam masalah ekonomi yang hanya mengandalkan penghasilan suami membuat perempuan atau para istri tidak berdaya jika tanpa kehadiran sosok suami dan tak jarang memberikan kekuatan bagi suami untuk memperlakukan istri semaunya. Hal ini menjadi salah satu pemicu terjadinya kekerasan dan perceraian. Kasus kekerasan terhadap perempuan dan anak dalam rumah tangga menjadi isu global yang tidak ada habisnya. Ketidakberdayaan perempuan menjadi landasan terjadinya pelecehan, kekerasan, dan perceraian. Oleh sebab itu perempuan harus diberdayakan. Pemberdayaan secara konsep merujuk pada kemampuan orang khususnya kelompok rentan dan lemah sehingga mereka memiliki kekuatan atau kemampuan untuk memenuhi kebutuhan dasar yang membuat kemandirian sehingga melahirkan freedom atau kebebasan (Ruhana, 2012).

Pemberdayaan dalam istilah asing disebut empowerment, secara leksikal pemberdayaan berarti penguatan. Pada tataran teknis istilah pemberdayaan dapat disamakan atau setidaknya diserupakan dengan istilah pengembangan. Bahkan keduanya memeliki sifat interchangeable atau dapat ditularkan (Machendrawaty \& Agus Ahmad Safei, 2016). Pemberdayaan atau pengembangan atau tepatnya pemberdayaan sumber daya manusia adalah upaya-upaya memperluas horizon pilihan bagi masyarakat. Dengan kata lain masyarakat diberdayakan agar bisa melihat dan memilih segala sesuatu yang bermanfaat bagi dirinya. Peneliti berpendapat bahwa masyarakat yang berdaya adalah masyarakat yang dapat memilih dan memiliki kesempatan untuk mengadakan pilihan-pilihan dalam kehidupannya. Pemberdayaan masyarakat harus menggunakan metode yang sesuai dengan kebutuhan masyarakat yang diberdayakan dan bersifat dinamis. Metode pemberdayaan harus disesuaikan dengan sumber daya yang tersedia dan bisa dimanfaatkan, serta harus mempertimbangkan lingkungan termasuk waktu dan tempat pemberdayaan masyarakat tersebut (Mardikanto, 2013).

Perempuan sebagai elemen masyarakat harus diberdayakan. Perempuan memiliki tugas yang langsung diberikan oleh alam yaitu 4M (menstruasi, mengandung, melahirkan, dan menyusi) yang secara kodrat tidak bisa digantikan oleh laki-laki (Suryadi \& Idris, 2004). Namun itu tidak menjadikan satu-satunya peran yang bisa dijalani, perempuan masih bisa terlibat di berbagai sektor. Setiap elemen masyarakat harus berdaya demi tercapainya suatu kesejahteraan, baik itu laki-laki ataupun perempuan.

Pemberdayaan Perempuan tidak terlepas dari proses pengembangan diri baik secara individu atau kelompok. Pengembangan diri terhadap kaum perempuan bisa dilakukan dengan berbagai macam cara seperti pemenuhan kebutuhan praktis, yaitu dengan pendidikan, kesehatan, dan ekonomi baik laki-laki maupun perempuan dan pemenuhan kebutuhan strategis yaitu dengan melibatkan perempuan dalam kegiatan pembangunan (Sumarti, 2010). Pemberdayaan perempuan menjadi krusial karena akan berdampak pada suatu keluarga yang terdiri dari beberapa orang. Perempuan yang berkualitas akan 
melahirkan keluarga yang berkualitas baik dalam bidang sosial dan ekonomi yang secara tidak langsung akan mempengaruhi kondisi sosial ekonomi masyarakat.

Dalam pandangan Islam antara kaum laki-laki dan kaum perempuan memiliki kodrat dan tabiat bawaan sejak lahir yang berbeda baik secara fisik maupun psikis. Makna filosofis yang terkandung dibalik penciptaan yang demikian adalah bahwa antara keduanya harus dapat bekerjasama dan berperan sesuai dengan kodrat dan tabiatnya masing-masing. Islam yang merupakan agama samawi telah menempatkan perempuan pada posisi yang terhormat dan mulia sesuai dengan kodrat dan tabiatnya, tidak berbeda dengan laki-laki karena keduanya memiliki peran masing-masing termasuk dalam kemanusiaan dan hak-hak masing-masing. Jadi suatu anggapan yang keliru jika menilai Islam adalah agama yang tidak ramah terhadap perempuan yang memicu diskriminasi terhadap kaum perempuan, sebagaimana konsep Islam itu sendiri bahwa laki-laki dan perempuan memiliki derajat yang sama di hadapan Tuhan yang membedakannya hanyalah tingkat ketaqwaannya (QS. Al-Hujurat: 13).

Meskipun banyak yang melandasi perempuan untuk merdeka tetap saja masih ada perempuanperempuan yang terpuruk. Untuk meminimalisir angka kemiskinan dan keterpurukan perempuan dibutuhkan forum-forum yang memfasilitasi para perempuan untuk saling berempati dan berbagi pengalaman untuk menyatukan kekuatan dengan memainkan fungsi dan perannya demi mewujudkan masyarakat adil makmur yang di Ridhoi Allah SWT.

Terdapat beberapa penelitian terdahulu mengenai pemberdayaan perempuan diantaranya, Pemberdayaan Perempuan Melalui Pelatihan Bahan Pangan Lokal yang ditulis oleh Wildan dkk, hasil penelitiannya menyebutkan bahwa indicator keenrhasilan program pemberdayaan perempuan dengan telah adanya pengembangan produk dan terbentuknya kemandirian tim dalam mengolah bahan pangan. (Saugi \& Sumarno, 2015). Penelitian terdahulu lainnya tentang Pemberdayaan Perempuan Miskin Kota Melalui Pendidikan yang ditulis oleh Leila Mona Ganiem, hasil penelitiannya menyatakan bahwa pemberdayaan perempuan melalui pendidikan nonformal berdampak positif karena relevan dengan kebutuhan masyarakat setempat dan mengoptimalkan sumber daya yang dimiliki masyarakat setempat.(Ganiem, 2016). Kemiripan dengan penelitian tersebut dari segi jenis pemberdayaan yang dilakukan melalui pendidikan nonformal namun yang menjadi kebaruan dari penelitian ini adalah program pemberdayaan perempuan yang ada merupakan program yang diluncurkan oleh pemerintah provinsi Jawa Barat.

Pemerintah mengambil bagian dalam meminimalisir permasalahan ini dibuktikan dengan beberapa program yang solutif dalam menjangkau permasalahan yang terjadi pada perempuan salah satunya adalah Sekoper Cinta. Program yang membidik kaum perempuan untuk mewujudkan kesetaraan peran, akses, partisipasi, control dan manfaat antara perempuan dan laki-laki dengan rentang usia minimal 18 tahun atau yang sudah menikah, dengan sasaran perempuan yang tinggal di daerah kumuh Kota dan atau Kabupaten di lingkup provinsi Jawa Barat. Penelitian ini bertujuan untuk mengetahui hasil program Sekoper Cinta dalam memberdayakan perempuan dengan berbagai metode dan konsepnya terkhusus di wilayah Kampung Munjul Tasikmalaya.

Penelitian ini menggunakan pendekatan kualitatif yang menggunkan metode deskriptif-analitis yang mendeskripsikan atau menggambarkan objek penelitian melalui data atau sampel seadanya tanpa 
melakukan analisis dan kesimpulan yang berlaku untuk umum (Sugiyono, 2017). Berdasarkan sumbernya data yang diperoleh terbagi menjadi dua yaitu data primer dan data sekunder. Data primer merupakan data yang diperoleh langsung dari sumbernya, seperti data terkait hasil wawancara dengan para fasilitator, anggota Sekoper Cinta, pihak Kelurahan Karikil, dan petugas dari DP3A (Dinas Pemberdayaan Perempuan dan Perlindungan Anak) Kota Tasikmalaya. Sedangkan data sekunder adalah data yang diperoleh dari sumbernya melalui perantara seperti dari dokumen-dokumen ataupun informasi dari instansi atau lembaga terkait program Sekoper Cinta.

\section{Hasil Penelitian}

Sekoper Cinta merupakan pendidikan non formal bagi perempuan di Provinsi Jawa Barat. Sekoper Cinta merupakan salah satu model pemberdayaan perempuan dengan mengembangkan leadership dalam memperjuangkan kesetaraan gender dan inklusif (Gerfianti S, 2019a). Sekoper Cinta hadir sebagai problem solving dalam menanggapi isu-isu keperempuanan di wilayah Provinsi Jawa Barat. Pelaksanaan program Sekoper Cinta yang berpedoman pada modul yang terdiri dari modul dasar dan modul tematik yang menjadikan kegiatan ini tersusun dan sistematis. Selain daripada peserta ada pihak lain yang harus ada dalam proses pemberdayaan yaitu harus adanya fasilitator. Salah satu peran penting fasilitator yaitu mendorong peserta agar dapat terlibat aktif dalam proses pemberdayaan serta memandu berjalannya proses pemberdayaan. Sebagaimana hasil wawancara yang telah dilakukan oleh peneliti bahwa Sekoper Cinta bisa diterima di masyarakat karena beberapa faktor seperti yang disampaikan oleh Ibu TT selaku fasilitator program Sekoper Cinta.

Sekoper Cinta menjadi tempat curahan hati ibu-ibu atau para istri mengenai kehidupan keluarga dan pribadinya, tidak bermaksud untuk saling membuka keburukan akan tetapi ini merupakan salah satu proses belajar, dengan adanya keterbukaan satu sama lain bisa memberikan pengalaman dan pengajaran. (Hasil Wawancara Ibu TT)

Sekoper Cinta hadir sebagai forum perempuan yang melibatkan perempuan sepenuhnya dalam setiap prosesnya. Materi yang disampaikan dan berbagai pelatihan diharapkan bisa membentuk pribadi baru, sebagaimana yang diungkapkan pada teori belajar operan dari Skinner (operant learning) mengenai perkembangan yang dihasilkan dari proses belajar (Sumanto, 2014).

Tabel 1. Proses Belajar (Gerfianti S, 2019b)

\begin{tabular}{ll}
\hline \multicolumn{1}{c}{ Tujuan } & \multicolumn{1}{c}{ Metode Belajar } \\
\hline Meningkatkan Pengetahuan & Ceramah, Membaca, Menonton, Tanya Jawab, dan \\
& lain-lain. \\
\hline Merubah Sikap (tidak mau menjadi mau) & $\begin{array}{l}\text { Diskusi dan berbagi, Melihat Contoh, Bermain Peran, } \\
\text { Refleksi. }\end{array}$ \\
\hline Meningkatkan Keterampilan & Bermain Peran, Praktek dan Pelatihan Tata boga, \\
& Tata rias, dan lain-lain.
\end{tabular}

Pada proses belajar dalam rangkaian pemberdayaan, posisi duduk harus diperhatikan. Berpacu pada buku pedoman ada beberapa posisi duduk yang cukup efektif untuk diterapkan. 


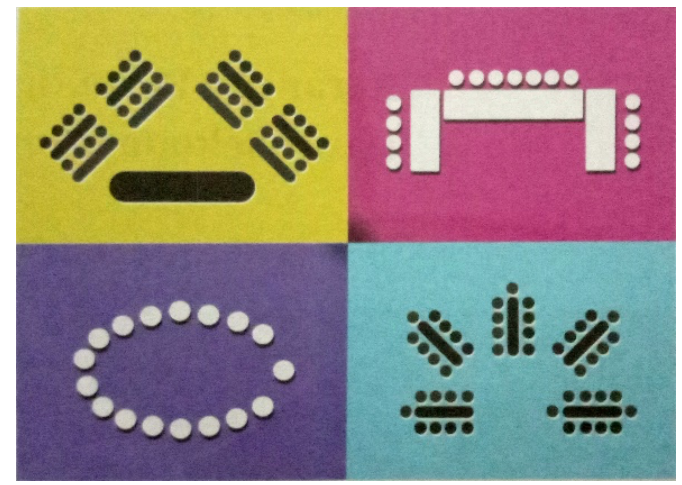

Gambar 1. Posisi Duduk

Berdasarkan hasil observasi peneliti mendokumentasikan data berupa prosedur kegiatan yang terdapat di pedoman dasar pelaksanakan program.

Tabel 2. Membangun Keluarga Bahagia

\begin{tabular}{|c|c|}
\hline Pengantar & $\begin{array}{l}\text { Komunikasi adalah kunci keharmonisan keluarga. Komunikasi yang } \\
\text { baik akan menciptakan keterbukaan dan saling pengertian. Pada } \\
\text { sesi ini peserta akan diingatkan Kembali mengenai prinsip-prinsip } \\
\text { komunikasi yang efektif. Diharapkan para peserta dapat } \\
\text { menerapkan pola komunikasi baik dan efektif dalam kehidupannya } \\
\text { sehari-hari. }\end{array}$ \\
\hline Tujuan & $\begin{array}{l}\text { 1. Peserta memahami cara berkomunikasi dengan setiap anggota } \\
\text { keluarga; } \\
\text { 2. Peserta mampu berkomunikasi secara efektif dalam } \\
\text { lingkungan keluarga. }\end{array}$ \\
\hline Pokok Bahasan & $\begin{array}{l}\text { 1. Pengertian komunikasi yang efektif; } \\
\text { 2. Komunikasi pasif, agresif dan asertif; } \\
\text { 3. Komunikasi asertif dalam kehidupan sehari-hari; } \\
\text { 4. Komunikasi dalam budaya sunda. }\end{array}$ \\
\hline Metode & $\begin{array}{l}\text { 1. Paparan; } \\
\text { 2. Diskusi; } \\
\text { 3. Bermain Peran. }\end{array}$ \\
\hline Alat dan Bahan & $\begin{array}{l}\text { 1. Lembar skenario; } \\
\text { 2. Papan tulis/lembar flipchart; } \\
\text { 3. Spidol. }\end{array}$ \\
\hline
\end{tabular}

\section{Aktivitas 1 : “Diskusi Perilaku Komunikasi” \\ Waktu : 20 Menit}

Langkah Kerja :

1. Menyapa peserta dengan senyuman, membuka sesi dengan saling bertanya kabar;

2. Sampaikan secara singkat mengenai topik bahasan pada pertemuan kali ini, yaitu mengenai komunikasi; 
3. Menanyakan pendapat peserta tentang komunikasi;

4. Menyimpulkan jawaban-jawaban peserta dan fasilitator menyampaikan pengertian komunikasi;

5. Fasilitator menanyakan beberapa hal terkiat komuniasi:

a. Kira-kira apa saja masalah yang ibu rasakan Ketika berkomunikasi dengan suami?

b. Kira-kira apa saja masalah yang ibu rasakan Ketika berkomunikasi dengan anak?

c. Kira-kira apa saja masalah yang ibu rasakan Ketika berkomunikasi dengan teman?

6. Bahas jawaban-jawaban dari para peserta, kemudian menyimpulkannya sebagai hambatan komunikasi.

7. Fasilitator menyampaikan faktor-faktor yang mempengaruhi komunikasi yang efektif.

8. Meminta perwakilan 4 orang peserta untuk maju yang kemudian akan memeragakan perilaku komunikasi yang agresif, pasif dan asertif.

9. Perwakilan yang sudahbersedia kedepan diberikan skenario dan meminta mereka memeragakannya dengan gerak, mimik dan intonasi yang sesuai.

10. Peragakan skenario dalam waktu 5 menit.

11. Membahas dengan peserta yang lain, kira-kira perilaku komunikasi mana yang terbaik untuk situasi tersebut.

12. Fasilitator memberikan penjelasan mengenai perilaku komunikasi. Menanyakan kepada peserta hambatan apa yang mereka rasakan Ketika tidak dapat melakukan perilaku komunikasi yang asertif dan apa yang seharusnya dilakukan?

13. Buat kesimpulan dari hasil diskusi tersebut.

14. Fasilitator memberikan kiat-kiat komunikasi efektif.

15. Akhiri kegiatan ini dengan bertepuk tangan.

\section{Aktivitas 2 : Tiga Bahasa Ajaib \\ Waktu :25 Menit \\ Langkah Kerja}

1. Untuk 5 menit pertama, berikan paparan mengenai Tiga Bahasa Ajaib yaitu "Terimakasih", "Tolong", dan "Maaf".

2. Bagi peserta menjadi tiga kelompok. Masing-masing diberi nama dengan tiga kata ajaib tersebut.

3. Masing-masing kelompok diberikan tugas berupa membuat skenario bermain peran sesuai dengan nama kelompoknya masing-masing. Minta peserta untuk mengambil contoh kejadian dalam kehiadupan mereka sehari. Misalnya, bagaimana orang tua meminta maaf kepada anaknya karena sudah marah berlebihan, atau istri yang berterima kasih pada hadiah yang di berikan suami.

4. Berikan kertas dan alat tulis, untuk tempat mereka menuliskan skenarionya secaea singkat. Durasi bermain peran adalah 5 menit. Minta juga kepada kelompok, untuk menentukansiapa saja yang akan berperan. Tidak perlu semua anggota menjadi pemain, namun dorong semuanya untuk aktif berdiskusi menentukan skenario. 
5. Waktu untuk berdiskusi dan mempersiapkan kelompok adalah 10 menit. Skenario tidak harus sempurna. Spontanitas terkadang justru memberikan ide-ide yang cemerlang.

6. Ketika semua kelompok sudah siap untuk tampil. Berikan tepuk tangan sebagai pembuka untuk mendorong semangat.

7. Tunjuk setiap kelompok untuk tampil bergiliran. Suasana pasti akan riuh dan meriah. Fasilitator bertugas untuk menjaga kondisi kelas tetap kondusif.

8. Berikan apresiasi kepada setiap kelompok yang telah tampil.

9. Setelah semuanya tampil, buat kesimpulan singkat, bahwa tiga kata ajaib tersebut dapat membuat berkomunikasi menjadi lebih baik dan efektif. Hubungan antar individu pun menjadi lebih harmonis.

10. Tutup kegiatan dengan tepuk tangan bersama dan bersiap untuk sesi berikutnya.

Kegiatan diatas merupakan salah satu data yang berhasil dikumpulkan oleh peneliti selama melakukan observasi dan wawancara ketika kegiatan berlangsung. Menurut hasil pengamatan kegiatan pemberdayaan yang dilakukan oleh Sekoper Cinta cenderung memperhatikan hal-hal yang dianggap kecil dan tidak terlalu penting, namun ternyata memiliki efek yang sangat besar.

Pada kegiatan di tabel no.2 menjelaskan mengenai materi tentang bagaimana menjalin komunikasi dalam keluarga, peserta Sekoper Cinta diberikan pemahaman tentang tata cara berkomunikasi yang baik dan nyaman yang setelah itu dipraktikan dalam kelompok kecil.

Beragam materi dan pelatihan yang diberikan dalam kegiatan Sekoper Cinta memberikan dampak yang aplikatif sehingga bisa langsung dipraktikan oleh peserta ketika acara telah selesai, seperti halnya dalam pemberian materi "Komunikasi Keluarga" peserta Sekoper Cinta dibekali PR untuk mencoba melakukan komunikasi yang harmonis Bersama suami, anak, orangtua, dan masyarakat untuk dilaporkan Kembali pada pertemuan selanjutnya.

Pelatihan yang dilakukan oleh program Sekoper Cinta telah mencetak perempuan-perempuan hebat yang mandiri, baik dalam keluarga, masyarakat, dan berpenghasilan secara ekonomi. Setelah peneliti melakukan wawancara dan observasi dengan beberapa peserta Sekoper Cinta, banyak di antara mereka yang membuka usaha sendiri atau mengembangkan usaha suami.

Beragam pelatihan yang dilakukan di Sekoper Cinta seperti pelatihan memasak, tata rias, budi daya jamur, dan pengelolaan keuangan. Pelatihan tata rias dalam program Sekoper Cinta menjadikan salah satu peserta Sekoper Cinta dengan inisial CY seorang tata rias yang sekarang sudah melebarkan sayapnya membuka jasa WO (wedding organizer) sebagaimana keterangan yang diberikan Ibu CY saat diwawancarai oleh peneliti sebagai berikut:

Saya merasa sangat beruntung bisa menjadi bagian dari peserta Sekoper Cinta, berkat pelatihan yang diberikan selama proses belajar, sekarang saya memulai kehidupan baru setelah mengalami berbagai kesulitan dalam kehidupan rumah tangga, Sekoper Cinta hadir sebagai motivator untuk saya dan ibu-ibu lainnya untuk selalu semangat. Pelatihan tata rias yang saya pelajari di Sekoper Cinta selain menghasilkan kemampuan dalam merias program ini juga berhasil membangun keberanian saya untuk mencoba membuka usaha jasa rias pengantian, alhamdulillah sedikit demi sedikit berkembang dan sekarang sedang merintis WO (wedding organizer) dan paket catering bersama ibu-ibu lain yang tertarik mudah-mudahan bisa terus berkembang.(Hasil Wawancara Ibu $\mathrm{CY}$ ) 
Dengan berbagai rangkaian kegiatan yang dilakukan di Sekoper Cinta yang merupakan sebuah wadah tempat berkumpulnya perempuan-perempuan di lingkup Jawa Barat saling bertukar ilmu dan pengalaman ternyata cukup efektif. Adanya sharing session membuka pemikiran para peserta Sekoper Cinta untuk terus maju dan berkembang. Sebagaimana hasil observasi dan wawancara yang dilakukan oleh peneliti dengan beberapa orang peserta Sekoper Cinta. Dengan banyaknya diskusi dan berbagi pengalaman, membuka peluang bisnis misalnya Ibu YN yang awalnya hanya sebagai pengrajin sendal biasa (home industry) kini sudah bisa mengembangkan usahanya lewat relasi dan masukan dari temanteman kelasnya di Sekoper Cinta, melakukan pemasaran melalui jejaring online, sehingga sudah banyak mengalami peningkatan, tidak hanya penghasilan yang bertambah jumlah pegawai pun bertambah sehingga secara tidak langsung sudah bisa memberdayakan sesamanya di lingkungan sekitarnya. Pernyataan ini berdasarkan hasil wawancara Bersama Ibu YN yang mengatakan:

Sekoper Cinta tidak hanya memberikan pengajaran dengan pengalamannya, akan tetapi menjadi perantara untuk bersilaturahmi jika tidak karena Sekoper Cinta saya tidak akan terlalu mengenal bahkan dekat dengan tetangga saya yang agak jauh rumahnya, sehingga mengikuti program ini menemukan keluarga baru, dan itu semua menambah keberkahan contohnya usaha saya yang terbantu pemasarannya oleh peserta Sekoper Cinta, dan setelah usaha saya sedikit demi sedikit mulai bangkit saya bisa merekrut beberapa peserta Sekoper Cinta untuk menambah penghasilan mereka. (Hasil wawancara ibu YN)

Peneliti berhasil mengumpulkan data yang salah satunya memuat berbagai feedback yang dirasakan dan diterima oleh peserta Sekoper Cinta, yaitu berupa timbulnya rasa percaya diri, pengetahuan mendasar tentang keperempuanan, tentang peran seorang perempuan dan seorang ibu, saling memotivasi antar sesama peserta, dan memberikan semangat serta penguatan untuk dapat mengembangkan diri melalui hobi dan potensi yang dimiliki oleh peserta yang beragam. Hal ini tentu menjawab konsep teori yang digunakan oleh peneliti yaitu kerangka berpikir Longwe yang menyatakan tentang pemberdayaan perempuan melalui suatu proses perubahan.

Kerangka berpikir Longwe menyatakan bahwa pemberdayaan perempuan merupakan suatu metode yang dilakukan untuk merubah sikap, memberikan pemahaman tentang peran perempuan dalam sebuah pembangunan, dan memberikan pemahaman bahwa seorang perempuan harus berdaya dan saling memberdayakan (Handayani, 2006). Teknis analisis Longwe mengembangkan metode pemberdayaan perempuan dengan lima kriteria analisis yang meliputi: kesejahteraan, akses, kesadaran kritis, dan partisipasi. Lima dimensi yang saling menguatkan, melengkapi, satu sama lain bersinergis dan bersifat dinamis. Teori Longwe diaplikasikan oleh Sekoper Cinta melalui berbagai materi yang telah disampaikan, seperti materi mengenai kodrat perempuan, yang memberikan pemaham tentang peran perempuan di ranah domestik maupun di ranah publik. Sebagai bentuk aktualisasi pemahaman peserta Sekoper Cinta mengenai peran perempuan, fasilitator memberikan pemahaman dan motivasi agar peserta Sekoper Cinta memahami dan mengetahui potensi yang dimiliki oleh masing-masing peserta melalui materi menggali potensi diri. Pernyataan ini diperkuat oleh pendapat salah satu narasumber yang berinisial RH selaku Sekretaris Lurah Kelurahan Karikil yang menyatakan:

Saya sangat bangga kepada peserta Sekoper Cinta yang sudah mulai berani unjuk diri untuk menyampaikan pendapat, mengikuti setiap pelatihan dengan sungguh tanpa rasa canggung karena sudah merasa nyaman dengan proses belajar di Sekoper Cinta, saya lihat ada beberapa peserta yang sudah menunjukan keahliannya dalam menjahit, menyulam dan merias wajah, mudahmudahan bisa terus berkembang seiring berjalannya waktu (Hasil wawancara ibu RH). 
Pendapat tersebut diperkuat oleh pernyataan Ibu IP selaku peserta Sekoper Cinta yang merasa lebih percaya diri setelah mengikuti program Sekoper Cinta yang menyediakan pelatihan tata rias, dengan pernyataannya sebagai berikut:

Pelatihan tata rias yang saya ikuti di Sekoper Cinta membantu saya meningkatkan kepercayaan diri dan meyakinkan diri bahwa saya memiliki potensi, kemampuan saya dalam tata rias tidak terlalu membuat saya percaya diri karena belum pernah mencoba untuk ditekuni, tapi sekarang sudah mulai berani dan yakin untuk menekuninya. (Hasil wawancara ibu IP)

Data di atas memberikan gambaran bahwa hal mendasar yang dilakukan di dalam proses pemberdayaan perempuan adalah menumbuhkan rasa percaya diri, menanamkan keinginan untuk terus berkembang dan mengenali potensi diri dengan mengoptimalkan peran perempuan itu sendiri baik sebagai seorang anak, istri, ibu, dan bagian dari masyarakat.

\subsection{Faktor Pendukung dan Penghambat}

Di keberjalanan kegiatan Sekoper Cinta mengalami naik turun terlebih dialami oleh peserta dibuktikan dengan intensitas kehadiran dan beberapa peserta yang mengundurkan diri. Sebagaimana teori belajar operan dari Skinner yang mengungkapkan segala sesuatu akan berulang dan berhenti tergantung dari respon yang didapat setelah melakukannya atau bsa disebut dengan istilah reinforcement (Sumanto, 2014). Secara umum pernyataan ini mengungkapkan mengenai reward dan punishment. Oleh karena itu, sangat penting bagi fasilitator untuk mengapresiasi atas segala perkembangan yang terjadi pada peserta Sekoper Cinta.

Reinforcement yang diterima oleh peserta Sekoper Cinta sangat beragam. Operant learning theory menyebutkan bahwa respon atau pengaruh setiap tindakan terdiri dari reinforcement positive dan reinforcement negative (Sumanto, 2014). Beberapa hal yang menghambat dan bahkan menghentikan proses pemberdayaan Sekoper Cinta dipengaruhi oleh reinforcement negative seperti yang diungkapkan salah satu peserta Sekoper Cinta berinisial WS yang harus berhenti dan keluar dari Sekoper Cinta:

Saya senang bisa berkumpul dan mengikuti sekoper Cinta, awalnya suami mengizinkan dan menandatangi pernyataan izin suami. Namun seiring berjalannya waktu karena saya terkadang ada acara kumpul dengan peserta Sekoper Cinta suami kurang suka, terlebih saya berprofesi buruh tani dan kemarin saya diminta untuk menggarap sawah oleh tetangga saya dan karena berbagai kebutuhan saya pun tidak bisa menolak. (Hasil wawancara ibu WS)

Ibu WS merupakan salah satu peserta yang tidak bisa diperjuangkan untuk bertahan di Sekoper Cinta, karena menyangkut suami yang tidak mengizinkan berbeda dengan Ibu GN yang berhenti dikarenakan sakit dan butuh istirahat total.

Berdasarkan data yang diterima oleh peneliti dari hasil observasi, wawancara, dan dokumentasi didapatkan beberapa faktor pendukung dan faktor penghambat dalam proses pemberdayaan yang dilakukan oleh program Sekoper Cinta di kampung Munjul, yaitu:

\section{a. Faktor Pendukung}

- Progam mendukung sesuai kebutuhan masyarakat terkhusus kaum perempuan;

- Fasilitas belajar yang cukup baik;

- Fasilitator yang sudah mumpuni di bidangnya; 
- $\quad$ Lingkungan yang bersahaja;

- Dukungan dari pemerintah setempat (RT, RW, dan Kelurahan);

- $\quad$ Respon dari pihak eksternal (masyarakat sekitar) yang bagus, sehingga lebih memotivasi;

- Pujian dari suami.

\section{b. Faktor Penghambat}

- Minim sarana dan prasarana;

- Jadwal yang terkadang bentrok;

- Masih adanya kelompok kecil yang terkadang membuat kurang nyaman bagi peserta yang lain;

- Izin suami.

Pelaksanaan program Sekoper Cinta di Kampung Munjul melakukan inovasi teknis berbeda tiap pertemuannya selain agar tidak jenuh, metode berganti posisi duduk ini membuat peserta Sekoper Cinta berbaur dan tidak sungkan satu sama lain sehingga menumbuhkan rasa kekeluargaan dan rasa nyaman mengikuti kegiatan. Program pemberdayaan perempuan menginginkan pengembangan modal potensi perempuan, dan akan lebih baik lagi jika pemberdayaan didukung oleh pengembangan kemampuan pemberdayanya. (Widjajanti, 2011)

Berdasarkan hasil observasi program Sekoper Cinta memuat beragam kegiatan yang salah satunya terdapat proses belajar yang bertujuan untuk meningkatkan pengetahuan, merubah sikap, dan meningkatkan keterampilan. Berbagai media dan metode pembelajaran yang digunakan untuk bisa mengefektifkan pemberian materi dan berbagai pelatihan seperti dengan melalui ceramah, menonton, tanya jawab, diskusi, bermain peran, dan juga melalui permainan lainnya yang dilakukan selama program berlangsung dan berkelanjutan. Oleh sebab itu peneliti menggunakan teori belajar operan dari Skinner (operant learning) mengenai perkembangan yang dihasilkan dari proses belajar yang dilakukan secara terus menerus.

\section{Kesimpulan}

Perempuan Kampung Munjul yang termasuk ke dalam kategori daerah kumuh di wilayah Kota Tasikmalaya Provinsi Jawa Barat telah membuktikan bahwa siapapun bisa memperoleh kehidupan yang baik dan layak tentunya dengan kemauan yang tinggi dan kerja keras. Mereka hanya membutukan fasilitator untuk memediasi dan mengarahkan untuk sebelumnya bisa mandiri. Pemberdayaan yang dilakukan oleh program Sekoper Cinta terhadap perempuan di Kampung Munjul cukup efektif dilihat dari data yang sudah didokumentasikan oleh peneliti yang didapatkan dari hasil observasi, wawancara, dan keterlibatan langsung yang dilakukan oleh peneliti.

Pemberdayaan perempuan oleh program Sekoper Cinta setidaknya bisa memberikan pengalaman dan pengajaran untuk lebih membuka pikiran dan memperhalus perasaan, sehingga bisa mendapatkan kehidupan yang lebih bahagia dengan cara yang berbeda. Sehingga dengan berdayanya kaum perempuan, kaum ibu, akan memberikan sumbangsih kesejahteraan sosial dan meminimalisir masalah sosial karena pada tiap rumah memiliki jantung yang sehat dan berkualitas yaitu seorang ibu. 


\section{Referensi}

Ganiem, L. M. (2016). Pemberdayaan Perempuan Miskin Kota Melalui Pendidikan. Jurnal Aspikom (Asosiasi Pendidikan Tinggi Ilmu Komunikasi), 3(2), 239-255.

Gerfianti S, M. S. (2019a). Modul Dasar: Sekoper Cinta Sekolah Perempuan Capai Impian dan Cita-cita,. Bandung: Tim Penyelenggara Sekoper Cinta.

Gerfianti S, M. S. (2019b). Modul Tematik: Sekoper Cinta Sekolah Perempuan Capai Impian dan Cita-cita. Bandung: Tim Penyelenggara Sekoper Cinta.

Handayani, T. \& S. (2006). Konsep dan Teknik Penelitian Gender. Edisi Revisi Cetakan kedua. Malang: UMM Press.

Machendrawaty, N., \& Agus Ahmad Safei. (2016). Pengembangan Masyarakat Islam. Bandung: Remaja Rosda Karya.

Mardikanto, S. (2013). Pemberdayaan Masyarakat dalam Perspektif Kebijakan Publik. Bandung: Alfabeta.

Ruhana, I. (2012). Pemberdayaan Sumber Daya Manusia VS Daya Saing Global. Jurnal Profit, 6(1), 5056.

Saugi, W., \& Sumarno, S. (2015). Pemberdayaan Perempuan Melalui Pelatihan Pengolahan Bahan Pangan Lokal. Jurnal Pendidikan Dan Pemberdayaan Masyarakat, 2(2), 226-238. https://doi.org/10.21831/jppm.v2i2.6361

Sugiyono. (2017). Metodologi Penelitian Kombinasi Mixed Methode. Bandung: Alfabeta.

Sumanto. (2014). Psikologi Perkembangan. Yogyakarta: CAPS.

Sumarti, T. (2010). Strategi Nafkah Rumah Tangga dan Posisi Kaum Perempuan Dalam Secercah Cahaya Menuju Kesejahteraan Perempuan (Sebuah Kajian). Jakarta: kementtrian Sosial RI: Direktorat Jendral Pemberdayaan Sosial.

Suryadi, A., \& Idris, E. (2004). Kesetaraan Gender. Bandung: PT Genesindo.

Widjajanti, K. (2011). Model Pemberdayaan Masyarakat. Jurnal Ekonomi Pembangunan, 12(1), 15-27.

Penghargaan: Saya mengucapkan terimaksih banyak kepada pihak yang telah membantu dalam pengerjaan penelitian ini, terutama kepada Dosen pembimbing skripsi, DP3A Kota Tasikmalaya, Kelurahan Karikil, dan juga peserta Sekoper Cinta. 